\title{
PENGARUH FRAUD AUDIT TRAINING, SKEPTISISME PROFESIONAL, DAN AUDIT TENURE PADA KEMAMPUAN AUDITOR DALAM MENDETEKSI KECURANGAN
}

\section{Kompiang Martina Dinata Putri ${ }^{1}$ Dewa Gede Wirama ${ }^{2}$ I Putu Sudana ${ }^{3}$}

\author{
${ }^{1}$ Fakultas Ekonomi dan Bisnis Universitas Udayana, Bali, Indonesia \\ ${ }^{1}$ Email: kompiang.martina@gmail.com \\ ${ }^{2}$ Fakultas Ekonomi dan Bisnis Universitas Udayana, Bali, Indonesia \\ ${ }^{3}$ Fakultas Ekonomi dan Bisnis Universitas Udayana, Bali, Indonesia
}

\begin{abstract}
ABSTRAK
Penelitian ini bertujuan untuk menganalisis pengaruhfraud audit training, skeptisisme profesional auditor, dan audit tenure pada kemampuan pendeteksian kecurangan. Sampel penelitian ini terdiri atas 42 auditor pada kantor akuntan publik di Bali pada tahun 2016. Pemilihan sampel dilakukan dengan teknik purposive sampling. Fraud audit training, skeptisisme profesional auditor, dan audit tenure diukur dengan menggunakan kuesioner. Teknik analisis data yang digunakan dalam penelitian ini adalah regresi linier berganda. Hasil analisis data menunjukkan bahwa fraud audit training, skeptisisme profesional auditor, dan, audit tenurememiliki pengaruh positif pada kemampuan pendeteksian kecurangan.
\end{abstract}

Kata kunci: fraud audit training, skeptisisme profesional, audit tenure, kemampuan pendeteksian kecurangan

\begin{abstract}
This study analyses the effect of fraud audit training, professional scepticism, and audit tenure on auditors' ability to detect fraud. The sample of this study consisted of 42 auditors from public accounting firm in Bali in 2016. Samples are selected using purposive sampling technique. Fraud audit training, professional scepticism, and audit tenure were measured by the use of questionnaires. Data analysis technique used in this research is multiple linear regression. The result showsthat fraud audit training, professional scepticism, and audit tenure have positive effects on auditors' fraud detection capabilities.
\end{abstract}

Keywords: fraud audit training, professional scepticism, audit tenure, fraud detection capabilities 
Kompiang Martina Dinata Putri, Dewa Gede Wirama, I Putu Sudana, Pengaruh Fraud......

\section{PENDAHULUAN}

Kasus-kasus mengenai kecurangan akuntansi beberapa tahun terakhir ini merupakan indikasi masih terjadinya kegagalan dalam dunia audit. Kecurangan atau fraud merupakan suatu istilah umum yang mencakup segala macam cara yang dapat digunakan dengan keahlian tertentu, yang dipilih oleh seorang individu untuk mendapatkan keuntungan dari pihak lain dengan melakukan representasi yang salah (Tunggal, 2016). Jadi fraud juga dapat dikatakan sebagai suatu perilaku atau tindakan penipuan yang sengaja dilakukan sehingga menimbulkan kerugian tanpa disadari oleh pihak lain dan memberikan keuntungan bagi pelaku kecurangan.

Maulana (2014) mengungkapkan salah satu kasus yang sempat ramai diberitakan adalah keterlibatan 10 kantor akuntan publik (KAP) Indonesia dalampraktik kecurangan keuangan. KAP-KAP tersebut diminta mengaudit 37bank sebelum terjadinya krisis keuangan pada tahun 1997. Hasil audit mengungkapkan bahwa laporan keuangan bank-bank tersebut sehat. Saat krisis menerpaIndonesia, bank-bank tersebut kolaps karena kinerja keuangannya sangat buruk. Hal ini terungkap dalam investigasi yang dilakukan pemerintah, yang kemudian menyimpulkan bahwa KAP-KAP tersebut terlibatdalampraktikkecurangan akuntansi. Selain kasus tersebut, masih ada kasus-kasuslain di Indonesia yang melibatkan auditor yang gagal mendeteksi kecurangan. Salah satu contoh kecurangan akuntansi adalah kasus yang menimpa akuntan publik Justinus Aditya Sidharta yang diindikasi melakukan manipulasi dalam mengaudit laporan keuangan PT Great River Internasional, Tbk. Justinus dianggap telah menyalahi aturan kode etik profesi akuntan, terutama yang berkaitan dengan integritas dan objektivitas. 
Akuntan publik Justinus Aditya Sidharta juga dianggap telah melakukan kebohongan publik karena tidak melaporkan kondisi keuangan Great River secara jujur(www.hukumonline.com, 2006). Kasus lainnya adalah kasus pada PT Kimia Farma di tahun 2001 yang dalam laporan keuangan auditannya melaporkan laba bersih sebesar Rp132 milyar, namun kemudian Kementerian BUMN dan Bapepam menyajikan kembali laporan keuangan tersebut dan menyatakan keuntungan perusahaan hanya sebesar Rp99,56 miliar, 24,7\% lebih rendah dari laba awal yang semula dilaporkan perusahaan. Auditor perusahaan dinyatakan tidak mampu mendeteksi kecurangan yang ada dalam laporan keuangan tersebut (Biksa dan Wiratmaja, 2016).

Kecurangan atau fraud semakin marak terjadi dengan berbagai cara yang terus berkembang sehingga kemampuan auditor dalam mendeteksi kecurangan perlu untuk terus ditingkatkan. Masalah yang timbul adalah auditor juga memiliki keterbatasan dalam mendeteksi fraud. Keterbatasan yang dimiliki auditor akan menyebabkan kesenjangan bagi pemakai jasa auditor yang berharap agar auditor dapat memberi keyakinan bahwa laporan keuangan yang disajikan tidak mengandung salah saji dan telah mencerminkan keadaan yang sebenarnya.

Pradanadkk.(2013) menyatakan bahwa kompetensi auditor mempengaruhi kemampuannyadalam mendeteksi suatu kecurangan yang mungkin terjadi. Banyak faktor yang diperkirakan menjadi penyebab auditor tidak mampu dalam mendeteksi kecurangan. Faktor-faktor tersebut bisa berasal dari sisi internal (dalam diri auditor) maupun maupun sisi eksternal. Lhaksmi (2014) menyatakan kurangnya pelatihan yang diikuti oleh seorang auditor bisa menjadi salah satu faktor yang menyebabkan 
Kompiang Martina Dinata Putri, Dewa Gede Wirama, I Putu Sudana, Pengaruh Fraud......

kemampuan auditor dalam mendeteksi kecurangan menurun. Hal ini didukung juga oleh penelitian yang dilakukan oleh Glover dkk. (2003)yang menyebutkan bahwa pelatihan mengenai pengetahuan tentang penipuan atau kecurangan akan memberikan dampak baik bagi auditor.

Haryanti (2013) menyatakan bahwa dengan adanya pelatihan mungkin menyebabkan struktur pengetahuan auditor tentang kekeliruan akan bertambah. Melalui pendidikan, pelatihan dan pengalaman auditor akan menjadi ahli di bidang akuntansi dan pengauditan, serta memiliki kemampuan untuk menilai dan mempertimbangkan secara objektif dan tidak memihak terhadap informasi dalam pembukuan perusahaan atau informasi lain yang berhasil diungkapkan melalui auditnya.Fullerton dan Durtschi (2004) juga menyimpulkan hal yang sama, yaitu terdapat perbedaan respon terhadap tanda-tanda kecurangan sebelum dan setelah fraudawareness training.

Karim dalam Lhaksmi (2014) mendefinisikan pelatihan sebagai suatu latihan kecakapan, kemahiran, ketangkasan dalam melaksanakan tugas. Selanjutnya dinyatakan pula bahwa pelatihan audit dirancang untuk meningkatkan kompetensi auditor dalam melakukan audit.Haryanti (2013) menyatakan bahwa pelatihan memiliki fungsi-fungsi edukatif, administratif dan profesional. Fungsi edukatif mengacu pada peningkatan kemampuan profesional, kepribadian, dedikasi dan loyalitas pada organisasi. Fungsi administrasi mengacu pada pemenuhan syaratsyarat administrasi, seperti promosi dan pembinaan karir. Salah satu pelatihan dalam pendeteksian kecurangan ialahfraud audit training, yaitu salah satu teknik 
atau pelatihan agar auditor mampu menginvestigasi dan mendeteksi kecurangan yang ada dalam laporan keuangan perusahaan (Lhaksmi, 2014).

Dalam penelitian ini fraud audit training dijelaskan dengan teori atribusi, dimana dikatakan keahlian profesional yang dimiliki melalui pelatihan, auditor harus dapat merumuskan pendapatnya dengan baik dan mampu mendeteksi kecurangan yang mungkin terjadi (Wahyudi dkk. 2013). Teori ini digunakan untuk mengembangkan penjelasan tentang cara-cara kita menilai individu secara berbeda, bergantung pada arti yang kita hubungkan dengan perilaku tertentu. Pada dasarnya, teori ini mengemukakan bahwa ketika mengobservasi perilaku seorang individu, kita berupaya untuk menentukan apakah perilaku tersebut disebabkan oleh faktor internal atau eksternal (Rayahu dan Gudono, 2016). Teori atribusi mengacu kepada penyebab suatu kejadian atau hasil yang diperoleh berdasarkan persepsi individu. Dalam penelitian ini teori atribusi menjelaskan pengaruh fraud audit training mempengaruhi auditor dalam melaksankan tugasnya dan tanggung jawabnya dalam mendeteksi suatu kecurangan yang mungkin terjadi.

Yunita (2013) juga menyatakan bahwa teori atribusi dapat mempengaruhi tingkat kinerja yang diharapkan di masa depan dalam tugas tertentu, tergantung pada penyebab khusus keberhasilan atau kegagalan sebelumnya dalam tugas yang sama. Untuk mencapai hasil yang diharapkan, auditor harus menggunakan kemahirannya untuk membuat pertimbangan. Namun kurangnya pemahaman yang komprehensip tentang fraud auditing khususnya dari para auditor internal perusahaan menjadi salah satu sebab tak terdeteksinya kasus-kasus yang terjadi di dalam perusahaan. Hal tersebut membuktikan bahwa tidak semua auditor yang 
Kompiang Martina Dinata Putri, Dewa Gede Wirama, I Putu Sudana, Pengaruh Fraud......

mengikuti pelatihan audit kecurangan dapat mengungkap kecurangan di dalam laporan keuangan tersebut.

Tingginya minat auditor dalam mengikuti pelatihan dapat memberi manfaat baik bagi auditor maupun perusahaan. Dengan telah mengikuti pelatihan, auditor lebih memahami prosedur audit yang harus ditambahkan dalam proses audit (Abdullatif, 2013). Sehubungan dengan hal tersebut maka hipotesis pertama dalam penelitian ini adalah

H1: Fraud audit training memiliki pengaruh positif pada kemampuanpendeteksian kecurangan.

Selain fraud audit training, sikap skeptisisme profesional juga sangat penting untuk dimiliki oleh setiap auditor. Hal ini didukung dengan penelitian Noviyanti (2008) yang menyatakan bahwa kurangnya skeptisisme profesional yang dimiliki oleh seorang auditor menyebabkan turunnya kemampuan auditor dalam mendeteksi kecurangan yang mungkin terjadi. Suryanto dkk. (2017) menyatakan bahwa skeptisme profesional (professional skepticism) adalah sikap perilaku (attitude) yang sarat pertanyaan dalam benak (quetining mind), waspada (being alert) pada keadaan-keadaan yang mengindikasi kemungkinan salah saji karena kesalahan (error) atau kecurangan (fraud) dan penilaian yang kritis (critical assessment) terhadap bukti. Sutrisno (2014) menyatakan bahwa skeptisisme profesional auditor merupakan sikap yang dimiliki auditor yang selalu mempertanyakan dan meragukan bukti audit. Dapat diartikan bahwa skeptisisme profesional menjadi salah satu faktor dalam menentukan kemahiran profesional seorang auditor.

Skeptisisme profesional auditor juga dapat dikatakan sebagai sebuah sikap yang menyeimbangkan antara sikap curiga dan sikap percaya. Pramana dkk. (2016) 
menyatakan bahwa skeptisisme adalah sikap kritis dalam menilai keandalan asersi atau bukti yang diperoleh, sehingga dalam proses audit auditor memiliki kepercayaan yang cukup tinggi pada pernyataan atau bukti yang telah diperoleh, serta mempertimbangkan kecukupan dan kesesuaian bukti yang diperoleh. Keseimbangan sikap antara percaya dan curiga ini tergambarkan dalam perencanaan dan prosedur audit yang dilakukan oleh akuntan publik. Di dalam dunia nyata, seringkali auditor tidak dapatmenyelaraskan antara sikap curiga dan percaya pada perusahaan yang diaudit.

Rahayu dan Gudono (2016) menyatakan sikap skeptisisme profesional digunakan auditor ketika melaksanakan pengumpulan bukti audit dan evaluasi kecukupan bukti audit. Sikap ini bukan berarti menuntun auditor untuk bersikap tidak percaya dan menganggap auditan berlaku tidak jujur pada saat pengumpulan dan evaluasi bukti. Tetapi, sikap ini ditunjukkan dengan sikap auditor yang tidak mudah merasa puas dan cukup dengan bukti yang kurang meyakinkan yang diberikan oleh manajemen.

Noviyanti (2008) menyatakan bahwa seorang auditor dalam menjalankan penugasan audit di lapangan seharusnya tidak hanya sekedar mengikuti prosedur audit yang tertera dalam program audit, tetapi juga harus disertai dengan sikap skeptisisme profesionalnya. Semakin tinggi skeptisisme seorang auditor dalam melakukan audit, maka semakin tinggi pula kemampuannya dalam mendeteksi kecurangan. Hadi dan Hardiyati (2014) yang menyatakan bahwa pengaruh skeptisisme profesional dapat dijelaskan oleh teori disonansi kognitif yang dikembangkan oleh Festinger pada tahun 1957. 
Kompiang Martina Dinata Putri, Dewa Gede Wirama, I Putu Sudana, Pengaruh Fraud......

Teori disonansi kognitif menjelaskan bahwa manusia pada dasarnya menyukai konsistensi.Oleh karena itu manusia akan cenderung mengambil sikap yang tidak bertentangan satu sama lain dan menghindari melakukan tindakan yang tidak sesuai dengan sikapnya. Teori ini membantu untuk menjelaskan bagaimana sikap skeptisisme auditor jika terjadi disonansi kognitif dalam dirinya ketika mendeteksi kecurangan (Noviyanti, 2008). Tingkat kepercayaan (trust) auditor yang tinggi terhadap klien akan menurunkan tingkat skeptisisme profesionalnya, dan sebaliknya. Sedangkan pemberian penaksiran risiko kecurangan (fraud risk assessment) yang tinggi dari atasan auditor kepada auditor akan meningkatkan skeptisisme profesionalnya, dan sebaliknya. Implementasi sikap skeptis akan mengurangi disonansi kognitif yang dialami oleh seorang auditor. Sehubungan dengan itu maka diajukan hipotesis kedua sebagai berikut.

H2: Skeptisisme profesional memiliki pengaruh positif pada kemampuan pendeteksian kecurangan.

Sarwoko (2014) menyatakan bahwa salah satu faktor yang mempengaruhi kemampuan auditor dalam mendeteksi kecurangan adalah masa perikatan. Chidkk. (2005) menyatakan bahwa independensi auditor semakin menurun bersamaan dengan bertambahnya jangka waktu perikatan audit pada klien yang sama. Namun Arensdkk. dalam Sarwoko (2014) menyatakan bahwa semakin lama auditor bekerja di klien yang sama, semakin baik mereka dalam mendeteksi risiko salah saji material dalam laporan keuangan, karena dengan pengalaman yang lebih lama mereka lebih memahami operasi bisnis klien, strategi bisnis klien, dan sistem internal kontrol klien dalam memproses laporan keuangannya. 
Audit tenure adalah lamanya waktu auditor melakukan pekerjaan audit secara berturut-turut terhadap suatu klien yang diukur berdasarkan jumlah tahun (Yanti dkk., 2015).Nanda (2015) menyatakan bahwa audit tenure merupakan jangka waktu perikatan yang terjalin antara KAP dengan auditee yang sama. Audittenureadalah lamanya waktu auditor melakukan pekerjaan audit secara berturut-turut terhadap suatu klien yang diukur berdasarkan jumlah tahun. Audit tenure yang panjang dapat meningkatkan kompetensi auditor karena auditor lebih mengenal seluk beluk bisnis klien, sehingga proses audit menjadi lebih efisien. Nanda (2015) juga menyatakan ketika auditor memiliki jangka waktu hubungan yang lama dengan kliennya maka akan terdapat pemahaman yang lebih atas kondisi keuangan klien dan oleh karena itu mereka akan lebih cepat mendeteksi masalah. Namun, audit tenure juga dapatmenggangu independensi auditor sehingga mengurangi motivasi auditor dalam mendeteksi kecurangan.

Siregardkk.(2012) menyatakan bahwa adanya audit tenure yang pendek tidak mempengaruhi baik kemampuan maupun kualitas audit yang dihasilkan oleh auditor tersebut. Sedangkan Ouyang dan Wan (2013) menyatakan bahwa audit tenure yang cukup lama akan sangat mempengaruhi independensi auditor sehinggadapat berdampak pada pendeteksian kecurangan.

Riset-riset terdahulu menemukan bahwa independensi auditor semakin menurun bersamaan dengan bertambahnya jangka waktu audit tenure pada klienklien yang sama (Chi dkk., 2005). Pengaruh audittenuredalam hal ini dijelaskan oleh teori keagenan (Jensen dan Meckling, 1976), dimana dikatakan bahwa lamanya hubungan perikatan auditor dengan klien (audit tenure) dapat 
Kompiang Martina Dinata Putri, Dewa Gede Wirama, I Putu Sudana, Pengaruh Fraud......

mempengaruhi kemampuan auditor dalam mendeteksi kecurangan dikarenakan adanya kepentingan manajemen klien. Pandangantersebut juga didukung oleh Sarwoko (2014). Auditor dapat menutupi kecurangan yang dilakukan oleh klien karena lamanya perikatan menciptakan hubungan baik antara auditor dan klien.

Jensen dan Meckling (1976) menyatakan bahwa teori keagenan mendeskripsi pemegang saham sebagai principal dan manajemen sebagai agen. Manajemen merupakan pihak yang dikontrak oleh pemegang saham untuk bekerja demi kepentingan pemegang saham. Manajemen diberikan sebagian kekuasaan untuk membuat keputusan bagi kepentingan terbaik pemegang saham, oleh karena itu manajemen wajib mempertanggungjawabkan semua upayanya kepada pemegang saham (Sukartha, 2007). Namun pada kenyataannya informasi yang simetris tidak pernah terjadi. Untuk menanggulangi hal tersebut maka agen memerlukan pihak ketiga yang independen yakni auditor. Pada akhirnya teori keagenan banyak berhubungan dengan permasalahan konflik kepentingan yang mungkin muncul dari hubungan kontraktual dari kedua belah pihak dimana pada hakekatnya keduanya memiliki akuisisi informasi yang berbeda. Oleh sebab itu dibutuhkan adanya pihak yang melakukan proses pemantauan dan pemeriksaan terhadap aktivitas yang dilakukan oleh pihak-pihak tersebut (Hartadi, 2012).

Paparan sebelumnya menunjukkan bahwa audit tenure dapat memiliki pengaruh yang positif maupuan negatif pada pendeteksian kecurangan oleh auditor. Sehubungan dengan itu maka diajukan hipotesis ketiga sebagai berikut.

H3: Audit tenuremempengaruhikemampuan pendeteksian kecurangan.

\section{METODE PENELITIAN}


Penelitian ini dilakukan pada tahun 2016 pada KAP di Provinsi Bali yang masih aktif dan terdaftar pada IAPI (Institut Akuntan Publik Indonesia). Objek penelitian ini adalah fraud audit training, skeptisisme profesional auditor, audit tenuredan kemampuan pendeteksian kecurangan. Penelitian ini menggunakansampel yang terdiri atas seluruh auditor yang masih aktif bekerja di KAP di Bali tahun 2016, yang memiliki pengalaman kerja minimal satu tahun. Sampel berjumlah57 orang.

Metode pengumpulan data yang digunakan dalam penelitian ini adalah metode survey dan data dikumpulkan melalui penyebaran kuesioner. Kuesioner diadopsi dari penelitian Lhaksmi (2014) untuk variabel fraud audit training, Oktaviani (2015) untuk variabel skeptisisme profesional, Sarwoko (2014) untuk variabel audit tenure dan Yunita (2013) untuk variabel kemampuan pendeteksian kecurangan. Kuesioner yang diadopsi pada penelitian ini menggunakan skala Likert untuk variabel skeptisisme profesional auditor, skala rasio untuk variabel fraud audit training, skala interval untuk variabel audit tenure dan kemampuan pendeteksian kecurangan.

Fraud Audit Training diukur dengan jumlah jam pelatihan yang telah diikuti oleh auditor. Skeptisisme profesional auditor diukur dengan tingkat keraguan auditor terhadap bukti audit, banyaknya pemeriksaan tambahan dan konfirmasi langsung, inisiatif seseorang untuk bersikap skeptis berdasarkan bukti yang diperolehnya dan tidak terlalu cepat mengambil keputusan. Variabel audit tenurediukur dengan lamanya masa perikatan audit yang dijelaskan melalui kuesioner dengan empat item pernyataan yang dikembangkan dari penelitian 
Kompiang Martina Dinata Putri, Dewa Gede Wirama, I Putu Sudana, Pengaruh Fraud......

Sarwoko (2014) dengan beberapa penyesuaian. Kemampuan pendeteksian kecurangan diukur dengan lingkungan perusahaan, pengetahuan tentang kecurangan, pendeteksian fraud symptoms (gejala-gajala kecurangan) dan kesanggupan dalam tahap pendeteksian kecurangan.

Teknik analisis data yang digunakan dalam penelitian ini adalah analisis regresi linear berganda untuk menguji pengaruh variabel-variabel independen terhadap variabel dependen. Model regresi dalam penelitian ini dinyatakan sebagai berikut:

$Y=\alpha+\beta_{1} X_{1}+\beta_{2} X_{2}+\beta_{3} X_{3}+\varepsilon$

di mana

\begin{tabular}{|c|c|}
\hline Y & $=$ Kemampuan Pendeteksian Kecurangan \\
\hline$\alpha$ & $=$ Konstanta \\
\hline$\beta 1, \beta 2, \beta 3$ & $=$ Koefisien regresi \\
\hline $\mathrm{X} 1$ & $=$ Fraud audit training \\
\hline X2 & $=$ Skeptisisme profesional auditor \\
\hline $\mathrm{X} 3$ & $=$ Audit Tenure \\
\hline
\end{tabular}

\section{HASIL DAN PEMBAHASAN}

Responden dalam penelitian ini adalah auditor pada KAP Provinsi Bali yang terdaftar di Institut Akuntan Publik Indonesia (IAPI) tahun 2016. Jumlah kuesioner yang disebarkan kepada auditor KAP di Bali sebanyak 57 kuesioner dan yang kembali sebanyak 42 kuesioner (response rate $=73,68 \%$ ).

Pengujian terhadap instrumen penelitian dilakukan dengan melakukan uji validitas dan reliabilitas. Instrumen yang valid adalah instrumen yang dapat mengukur apa yang seharusnya diukur dan instrumen yang reliabel adalah 
instrumen yang bila digunakan beberapa kali atau oleh orang yang berbeda untuk mengukur suatu objek yang sama akan menghasilkan data yang sama.

Hasil pengujian menunjukkan seluruh nilai koefisien korelasi dari instrumen ini lebih besar dari 0,3, sehingga instrumen penelitian ini dapat dikatakan valid atau instrumen ini dapat mengukur apa yang seharusnya diukur. Hasil uji reliabilitas yang ditampilkan pada Tabel 1 menunjukkanseluruhinstrumen penelitian dapat dikatakan reliabel (Cronbach'salpha lebih besar dari 0,6).

Tabel1.

Uji Reliabilitas

\begin{tabular}{lcc}
\hline \multicolumn{1}{c}{ Variabel } & Cronbach's Alpha & Keterangan \\
\hline Skeptisisme Profesional Auditor & 0,892 & Reliabel \\
Audit Tenure & 0,836 & Reliabel \\
Kemampuan Pendeteksian Kecurangan & 0,891 & Reliabel \\
Sumber: Data primer diolah, 2016 & &
\end{tabular}

Uji normalitas bertujuan untuk menguji apakah residual regresi berdistribusi.

Model regresi yang baik adalah model yang memiliki residual yang terdistribusi normal atau mendekati normal. Pengujian normalitas data dilakukan dengan uji Kolmogorov-Smirnov. Hasil uji pada Tabel 2. menunjukkan nilai KolmogorovSmirnovsebesar 0,591 atau lebih besar dari $\alpha=0,05$ dan nilai koefisien Asymp. sig (2-tailedsebesar $0,876>\alpha=0,05)$. Sehingga dapat disimpulkan bahwa data yang digunakan dalam persamaan regresi merupakan data yang terdistribusi dengan normal.

Tabel 2.

Uji Normalitas 


\begin{tabular}{ll}
\hline & Unstandardized Residual \\
\hline $\mathrm{N}$ & 42 \\
Kolmogorov-Smirnov $\mathrm{Z}$ & 0,591 \\
Asymp. Sig. (2-tailed) & 0,876 \\
\hline Sumber: Data primer diolah, 2016 &
\end{tabular}

Uji heterokedastisitas dilakukan untuk memastikan bahwa model regresi tidak mengandung ketidaksamaan varian. Untuk mendeteksi ada atau tidaknya heterokedastisitas digunakan model Glejser, dengan syarat nilai signifikansi berada di atas 0,05 yang berarti tidak terdapat heteroskedastisitas (Ghozali, 2016:134). Tabel 3 memperlihatkan tingkat signifikansi tiap variabel bebas di atas 0,05 sehingga dapat disimpulkan model regresi terbebas dari heteroskedastisitas.

\section{Tabel 3. Uji Heteroskedastisitas}

\begin{tabular}{clcc}
\hline No & \multicolumn{1}{c}{ Variabel } & Sig. & Keterangan \\
\hline 1 & Fraud Audit Training & 0,581 & Bebas heteroskedastisitas. \\
2 & Skeptisisme Profesional Auditor & 0,646 & Bebas heteroskedastisitas. \\
3 & Audit Tenure & 0,396 & Bebas heteroskedastisitas. \\
\hline Sumber: Data primer diolah, 2016 & & &
\end{tabular}

Uji multikolinieritas dimaksudkan untuk membuktikan atau menguji ada atau tidaknya hubungan antar variabel bebas. Hasil uji multikolinearitas pada Tabel 4. menunjukkan bahwa nilai tolerance variabel bebas berada di atas 0,1 dan nilai VIF berada di bawah 10. Jadi dapat disimpulkan bahwa model tidak terdapat gejala multikolinearitas.

\section{Tabel 4.}




\section{Uji Multikolinearitas}

\begin{tabular}{clcc}
\hline No & \multicolumn{1}{c}{ Variabel } & Nilai Tolerance & Nilai VIF \\
\hline 1 & Fraud Audit Training & 0,635 & 1,575 \\
2 & Skeptisme Profesional Auditor & 0,415 & 2,410 \\
3 & Audit Tenure & 0,530 & 1,888 \\
\hline Sumber: & Data primer diolah, 2016
\end{tabular}

Statistik deskriptif dalam penelitian ini disajikan untuk memberikan informasi tentang karakteristik variabel penelitian, antara lain nilai mean dan deviasi standar.

Tabel 5.

Statistik Deskriptif

\begin{tabular}{|c|c|c|c|c|c|}
\hline & $\mathbf{N}$ & Min. & Maks. & $\begin{array}{c}\text { Rata- } \\
\text { rata }\end{array}$ & $\begin{array}{c}\text { Deviasi } \\
\text { Standar }\end{array}$ \\
\hline Fraud Audit Training & 42 & 12,00 & 36,00 & 27,29 & $\overline{8,06}$ \\
\hline Skeptisisme Profesional Auditor & 42 & 12,00 & 26,00 & 18,98 & 3,81 \\
\hline Audit Tenure & 42 & 10,00 & 22,00 & 15,57 & 3,07 \\
\hline $\begin{array}{l}\text { Kemampuan Pendeteksian } \\
\text { Kecurangan }\end{array}$ & 42 & 8,70 & 9,90 & 9,39 & 0,27 \\
\hline
\end{tabular}

Tabel 5 menunjukkan jumlah responden adalah 42. Rata-rata respon responden akan diklasifikasi dengan tahapan sebagai berikut.

1) Menghitung Jangkuan yaitu: Nilai terbesar - Nilai Terkecil

Tabel 6.

Nilai Jangkauan

\begin{tabular}{lccc}
\hline \multicolumn{1}{c}{ Variabel } & $\begin{array}{c}\text { Nilai } \\
\text { Terbesar }\end{array}$ & $\begin{array}{c}\text { Nilai } \\
\text { Terkecil }\end{array}$ & Jangkauan \\
\hline Fraud Audit Training & 36 & 12 & 24 \\
Skeptisisme Profesional Auditor & 26 & 12 & 14 \\
Audit Tenure & 22 & 10 & 12 \\
Kemampuan Pendeteksian Kecurangan & 9,90 & 8,70 & 1,20 \\
\hline
\end{tabular}

Sumber: Data primer diolah, 2016 
Kompiang Martina Dinata Putri, Dewa Gede Wirama, I Putu Sudana, Pengaruh Fraud......

2) Menghitung banyaknya kelas interval adalah 3 (tiga) kelas dengan klasifikasi rendah, cukup tinggi, dan tinggi.

3) Panjang interval kelas diperoleh melalui pembagian jangkauan dengan jumlah kelas, hasilnya adalah sebagai berikut.

Tabel 7.

Interval Kelas

\begin{tabular}{lccc}
\hline \multicolumn{1}{c}{ Variabel } & Jangkauan & $\begin{array}{c}\text { Jmlah } \\
\text { Kelas }\end{array}$ & $\begin{array}{c}\text { Panjang } \\
\text { Interval kelas }\end{array}$ \\
\hline Fraud Audit Training & 24 & 3 & 8,00 \\
Skeptisisme Profesional Auditor & 14 & 3 & 4,67 \\
Audit Tenure & 12 & 3 & 4,00 \\
Kemampuan Pendeteksian Kecurangan & 1,20 & 3 & 0,40 \\
\hline
\end{tabular}

Sumber: Data primer diolah, 2016

Berdasarkan nilai maksimum dan nilai minimum jawaban responden serta panjang kelas interval maka masing-masing variabel penelitian dapat diklasifikasi seperti tersaji pada Tabel 8 .

Tabel 8.

Klasifikasi Variabel Penelitian

\begin{tabular}{lccc}
\hline \multicolumn{1}{c}{ Variabel } & $\begin{array}{c}\text { Rentang } \\
\text { Klasifikasi }\end{array}$ & Klasifikasi & $\begin{array}{c}\text { Rata-rata } \\
\text { Respon }\end{array}$ \\
\hline \multirow{2}{*}{ Fraud Audit Training } & $12-20,00$ & Rendah & \\
& $20,01-28,01$ & Cukup tinggi & 27.29 \\
& $28,02-36,02$ & Tinggi & \\
Skeptisisme Profesional Auditor & $12-16,67$ & Rendah & 18.98 \\
& $16,68-21,35$ & Cukup tinggi & \\
& $21,36-26,03$ & Tinggi & 15.57 \\
Audit Tenure & $10-14,01$ & Rendah \\
& $14,02-18.02$ & Cukup tinggi & \\
Kemampuan Pendeteksian & $18,03-22.03$ & Tinggi & \\
Kecurangan & $8.70-9,10$ & Rendah & \\
& $9,11-9,51$ & Cukup tinggi & \\
\hline Sumber: Data primer diolah 2016 & $9,52-9,92$ & Tinggi &
\end{tabular}

Sumber: Data primer diolah, 2016 
Variabel fraud audit training memiliki nilai minimum sebesar 12 dan nilai maksimum 36. Rata-rata respon responden yang menjawab pertanyaan didalam kuisioneruntuk variabel fraud audit trainingsebesar 27,29, terklasifikasi cukup tinggi dimana sebagian besar responden memiliki tingkat jawaban yang cukup tinggi dalam hal jumlah jam pelatihan yang pernah diikuti.

Variabel skeptisisme profesional auditor memiliki nilai minimum sebesar 12 dan nilai maksimum 26. Rata-rata respon responden yang menjawab pernyataandalam kuesioner untuk variabel skeptisisme profesional auditor sebesar 18,98, terklasifikasi cukup tinggi dimana sebagian besar responden memiliki tingkat jawaban setuju dalam indikator-indikator skeptisisme profesional.

Variabel audit tenure memiliki nilai minimum sebesar 10 dan nilai maksimum 22. Rata-rata respon responden yang menjawab pertanyaan dalam kuesioner untuk variabel audit tenure sebesar 15,57, terklasifikasi cukup tinggi dimana sebagian besar responden memilih waktu perikatan yang tidak terlalu lama dan tidak terlalu pendek didalam indikator audit tenure yaitu lamanya masa perikatan audit.

Variabel kemampuan pendeteksian kecurangan memiliki nilai minimum sebesar 8,70 dan nilai maksimum 9,90. Rata-rata respon responden yang menjawab pernyataan dan pertanyaan di dalam kuesioner untuk variabel kemampuan pendeteksian kecurangan sebesar 9,39, terklasifikasi cukup tinggi dimana responden cenderung menilai diri mereka memiliki kemampuan pendeteksian yang tinggi dengan memberikan nilai persentase yang cukup tinggi yakni di antara 70100 persen. 
Kompiang Martina Dinata Putri, Dewa Gede Wirama, I Putu Sudana, Pengaruh Fraud......

Analisis regresi linear berganda digunakan untuk mengetahui pengaruh fraudaudit training $\left(\mathrm{X}_{1}\right)$, skeptisisme profesional auditor $\left(\mathrm{X}_{2}\right)$ dan audit tenure $\left(\mathrm{X}_{3}\right)$ pada kemampuan pendeteksian kecurangan (Y). Hasil analisis disajikan dalam Tabel 9.

Tabel 9.

Analisis Regresi Linear Berganda

\begin{tabular}{|c|c|c|c|c|c|}
\hline \multirow{2}{*}{ Variabel } & \multicolumn{2}{|c|}{$\begin{array}{l}\text { Unstandardized } \\
\text { Coefficients }\end{array}$} & \multirow{2}{*}{$\begin{array}{c}\text { Standardized } \\
\text { Coefficients } \\
\text { Beta }\end{array}$} & \multirow[t]{2}{*}{$\begin{array}{c}\text { t- } \\
\text { hitung }\end{array}$} & \multirow[t]{2}{*}{ Sig. } \\
\hline & B & $\begin{array}{l}\text { Std. } \\
\text { Error }\end{array}$ & & & \\
\hline (Constant) & 8,270 & 0,151 & & 54,668 & 0,000 \\
\hline Fraud Audit Training & 0,009 & 0,004 & 0,283 & 2,240 & 0,031 \\
\hline Skeptisisme Profesional Auditor & 0,025 & 0,011 & 0,353 & 2,260 & 0,030 \\
\hline Audit Tenure & 0,025 & 0,012 & 0,286 & 2,070 & 0,045 \\
\hline Adjusted R-square & & & & & 0,585 \\
\hline $\begin{array}{l}\text { F-hitung } \\
\text { Sig.F }\end{array}$ & & & & & $\begin{array}{r}20,277 \\
0,000\end{array}$ \\
\hline
\end{tabular}

Sumber: Data primer diolah, 2016

Model regresi yang digunakan dalam penelitian ini dapat dianggap layak karena nilai $F_{\text {hitung }}$ sebesar 20,277 memiliki tingkat signifikansi yang lebih kecil dari 0,05. Berdasarkan nilai $\mathrm{R}^{2}$ (adjusted) sebesar 0,585 dapat dikatakan bahwa 58,5 persen kemampuan pendeteksian kecurangan auditor dijelaskan oleh fraud audit training, skeptisisme profesional auditor, dan audit tenure.

Hipotesis pertama menyatakan bahwa fraud audit training memiliki pengaruh positif pada kemampuan pendeteksian kecurangan.Tabel 9menunjukkan nilai thitung variabel fraud audit trainingadalah2,240dengan signifikansi 0,031 (tidak melebihi 0,05). Hal ini memiliki arti bahwa fraud audit trainingmemiliki pengaruh positif pada kemampuan pendeteksian kecurangan, dan dengan demikian maka hipotesis pertama penelitian ini diterima. Semakin banyak seorang auditor 
mengikuti pelatihan maka semakin tinggi kemampuan auditor tersebut dalam mendeteksi kecurangan. Keahlian profesional yang dimiliki melalui pelatihan memungkinkan auditor merumuskan pendapatnya dengan baik dan mampu mendeteksi kecurangan yang mungkin.Hasil penelitian ini sesuai dengan teori atribusi, dimana dikatakan keahlian profesional yang dimiliki melalui pelatihan, auditor harus dapat merumuskan pendapatnya dengan baik dan mampu mendeteksi kecurangan yang mungkin terjadi (Wahyudi, dkk 2013). Teori atribusi mengacu kepada penyebab suatu kejadian atau hasil yang diperoleh berdasarkan persepsi individu. Dalam penelitian ini teori atribusi menjelaskan pengaruh fraud audit training mempengaruhi auditor dalam melaksanakan tugasnya dan tanggungjawabnya dalam mendeteksi suatu kecurangan yang mungkin terjadi. Hasil penelitian ini sejalandengan penelitian dari Rahayu dan Gudono (2016) yang menunjukkan bahwapelatihan audit kecurangan menjadi faktor paling signifikan yang mempengaruhi kemampuan auditor BPKP Kalimantan Barat dalam mendeteksi. Dinyatakan bahwa pengetahuan yang didapatkan melalui pelatihan akan mempertajam insting auditor sehingga akan membantu kesuksesan mereka dalam pendeteksian kecurangan.Hasil penelitian ini juga mendukung penelitian Haryanti (2013) yang menyatakan bahwa ada pengaruh yang positif antara pelatihan auditor dengan pengetahuan tentangkekeliruan, dan dengan demikian dapat dikatakan bahwa apabila pelatihan auditor secara kuantitas dan kualitas semakin baik maka akan semakin meningkat pengetahuan yang dimiliki auditor tentangkekeliruan.Hasil penelitian ini tidak sejalan dengan penelitian Lhaksmi (2014) yang menunjukkan bahwa pelatihan audit kecurangan ternyata tidak terbukti 
Kompiang Martina Dinata Putri, Dewa Gede Wirama, I Putu Sudana, Pengaruh Fraud......

berpengaruh terhadap kemampuan auditor dalam mendeteksi kecurangan. Namun demikian, Asare dkk. (2015)menyatakan bahwa pelatihan sangatlah penting bagi suatu individu seorang auditor guna meningkatkan kemampuan yang dimiliki oleh auditor tersebut. Salah satu pelatihan yang dapat diminati dalam meningkatkan kemampuan pendeteksian kecurangan saat ini ialah pelatihan akuntansi forensik untuk memahami atau mempelajari kecurangan dalam audit (Ramaswamy, 2007).

Hipotesis kedua menyatakan bahwa skeptisisme profesional auditor memiliki pengaruh positif pada kemampuan pendeteksian kecurangan. Tabel 9menunjukkan nilai thitungvariabel skeptisisme profesional auditor adalah2,260 dengan signifikansi 0,030 (tidak melebihi 0,05).Hal ini memiliki arti bahwa skeptisisme profesional auditor berpengaruh positif pada kemampuan pendeteksian kecurangan, dan dengan demikian maka hipotesis kedua penelitian ini diterima.Skeptisisme profesional yang tinggi akan memberi dampak bagi kinerja auditor. Skeptisisme profesional dapat digunakan ketika seorang auditor menelaah bukti audit yang sudah ada, kemudian mendeteksi sinyal atau tanda kemungkinan kecurangan yang terdapat dalam suatu laporan keuangan. Teori disonansi kognitif membantu menjelaskan bagaimana auditor menggunakan skeptisisme profesionalnya jika terjadi disonansi antara perilaku dan sikap (Hadi dan Hardiyati, 2014). Teori disonansi kognitif juga membantu menjelaskan apakah dengan skeptisisme profesional auditor terpengaruh atau tidak dengan fraud risk assessment (penaksiran risiko kecurangan) yang rendah yang ditetapkan oleh atasannya, padahal auditor sebenarnya mempunyai tingkat kepercayaan yang rendah terhadap klien. 
Hasil penelitian ini sejalan dengan hasil penelitianAdnyani dkk. (2014),yang menyatakan bahwa skeptisisme profesional auditor berpengaruh positifpada tanggungjawab auditor. Auditor bertanggungjawab untuk merencanakan dan menjalankan audit untuk mendapatkan keyakinan yang memadai dalam mendeteksi kecurangan dan kekeliruan yang material, sehingga sangat penting bagi auditor memiliki skeptisisme profesional agar nanti bukti yang dikumpulkan dapat dijadikan dasar dalam memberikan opini audit. Hasil penelitian ini juga mendukung penelitian Lhaksmi (2014) yang menyatakan skeptisisme profesional berpengaruh positifpadakemampuan auditor dalam mendeteksi kecurangan dalam konteks audit internal.Penelitian Idawati dan Gunawan (2015) juga menunjukkan bahwa skeptisisme profesional berpengaruh positif pada kemampuan auditor untuk mendeteksi kecurangan, dimana dikatakan penting bagi auditor untuk memiliki skeptisisme profesional sehingga bukti yang dikumpulkan kemudian dapat digunakan sebagai dasar untuk memberikan opini audit. Skeptisisme profesional akan membantu auditor dalam menilai risiko kritis yang dihadapi dan memperhitungkan risiko dalam berbagai keputusan.Penelitian ini juga sejalan dengan hasil penelitian Anggriawan (2014) yang menyatakan bahwa skeptisisme profesional berpengaruh positif terhadap kemampuan auditor dalam mendeteksi fraud. Sikap skeptis harus dimiliki oleh seorang auditor dalam pelaksanaan audit, sehingga auditor tidak percaya begitu saja pada asersi yang diberikan manajemen, namun harus dapat menemukan bukti yang mendukung asersi tersebut. Namun, hasil penelitian ini tidak sejalan dengan penelitian yang dilakukan dari Rahayu dan Gudono (2016) yang menyatakan bahwa skeptisisme profesional tidak 
Kompiang Martina Dinata Putri, Dewa Gede Wirama, I Putu Sudana, Pengaruh Fraud......

mempengaruhi kemampuan auditor dalam mendeteksi kecurangan yang dikarenakan adanya perbedaan level skeptisisme auditor, nature pelaku kecurangan wilayah Kalimantan Barat yang dinilai berani dan memiliki intelektual yang tinggi, dan indikator yang digunakan untuk mengukur skeptisisme menjadi faktor-faktor yang membuat skeptisisme profesional belum mampu mempengaruhi kemampuan auditor yang bekerja di BPKP Perwakilan Kalimantan Barat.Penelitian ini tidak sejalan dengan penelitian yang dilakukan Suryanto dkk. (2017) yang menyatakan bahwa skeptisisme profesional tidak berpengaruh pada kemampuan auditor dalam mendeteksi kecurangan, dikarenakan penelitian ini dilakukan di Yogyakarta dan Surakarta dimana karakteristik dari dalam diri auditor yang mayoritas darietnis Jawa yang cenderung memiliki sikap pemalu, sungkan, ramah dan mempertahankan keharmonisan hubungan baik di depan orang lain. Akibatnya, ketika terdeteksi suatu kecurangan yang ada di lapangan saat audit dilakukan, auditor dari etnis Jawa bisa saja akan berupaya menghindari konflik dengan auditan, demi menjaga hubugan baik yang telah terjalin.

Hipotesis ketiga menyatakan bahwa audit tenure mempengaruhi kemampuan

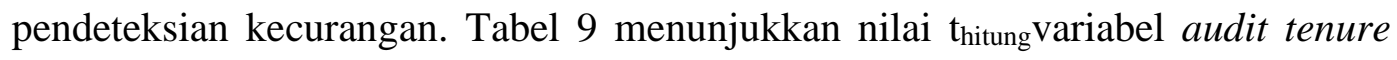
sebesar2,070 dengan signifikansi 0.045 (tidak melebihi 0,05). Hal ini memiliki arti bahwa audit tenure berpengaruh pada kemampuan pendeteksian kecurangan, dan dengan demikian maka hipotesis ketiga dalam penelitian ini diterima.Lamanya hubungan antara auditor dengan klienmembuat auditor lebih memahami dan mengetahui kondisi keuangan perusahaan, sehingga mempermudah pemeriksaan dan mendeteksi kecurangan. Praptika danRasmini (2016) menyatakan 
bahwaseorang auditor yang memiliki penugasan cukup lama dengan perusahaan klien akan mendorong terciptanya pengetahuan bisnis sehingga memungkinkan auditor untuk merancang program audit yang efektif dan laporan keuangan audit yang berkualitas tinggi.Hal ini sejalan dengan teori keagenan yang dimana dikatakan bahwa sesorang auditor dengan kualitas audit yang tinggi akan memiliki kemampuan dalam mendeteksi adanya kecurangan yang dilakukan oleh klien. Audit tenure dalam hal ini juga menjadi sebuah indikasi bahwa sikap independen auditor yang sesungguhnya menjadi sangat sulit untuk diterapkan, karena adanya kepentingan manajemen klien. Oleh karena itu, lamanya hubungan perikatan auditor dengan klien dapat mempengaruhi kemampuan auditor dalam mendeteksi kecurangan. Sesuai dengan teori keagenan diharapkan auditor mampu mempertahankan sikap independensinya tanpa memandang masa perikatan yang terjalin cukup lama dengan klien sehingga kemampuan pendeteksian kecurangan tetap terjaga.Hasil penelitian ini sejalan dengan penelitianSarwoko (2014) yang menyatakan bahwa masa perikatan audit memiliki pengaruh positif pada penerapan prosedur audit untuk mendeteksi risiko kecurangan dalam laporan keuangan. Hasil penelitian ini juga mendukung penelitian Arens dkk. dalam Sarwoko, (2014) yang menyatakan bahwa semakin lama auditor bekerja pada klien yang sama, semakin baik kemampuannya dalam mendeteksi risiko salah saji material dalam laporan keuangan. Namun hasil penelitian ini tidak konsisten dengan hasil penelitian yang dilakukan oleh Deis dan Giroux (1992) yang menyatakan bahwa semakin panjang masa perikatan audit, maka semakin akrab hubungan auditor dengan kliennya sehingga dapat mengurangi independensi auditor yang pada akhirnya akan 
mengurangi kualitas audit. Secara umum, hasil penelitian ini menunjukkan bahwa dengan adanya perikatan audit yang terjalin cukup lama maka akan meningkatkan kemampuan seorang auditor dalam mendeteksi suatu kecurangan, tanpa mengurangi sikap independensi dari auditor tersebut.

\section{SIMPULAN DAN SARAN}

Penelitian ini menghasilkan tiga simpulanberdasarkan hasil analis data dan pembahasan yang telah dilakukan. Pertama, fraud audit training berpengaruh positif pada kemampuan pendeteksian kecurangan, yang berarti bahwa semakin banyak seorang auditor mengikuti fraud audit trainingmaka semakin tinggi kemampuannya dalam mendeteksi kecurangan yang mungkin terjadi dalam laporan keuangan klien yang diauditnya. Kedua, skeptisisme profesional auditor berpengaruh positif pada kemampuan pendeteksian kecurangan, yang berarti bahwa semakin tinggi sikap skeptisisme yang dimiliki seorang auditor maka semakin tinggi pula kemampuannya dalam mendeteksi suatu kecurangan. Ketiga, audit tenure berpengaruh positif pada kemampuan pendeteksian kecurangan, yang berarti bahwa semakin lama masa perikatakan audit semakin tinggi kemampuan seorang auditor dalam mendeteksi suatu kecurangan. Simpulan ketiga tersebut dapat dipandang sebagai indikasi bahwa audit tenure ternyata tidak mengganggu independensi auditor.

Penelitian ini terbatas pada persepsi auditor KAPyang pekerjaannya melingkupi sektor swasta saja. Penelitian selanjutnya dapat melakukan perbandingan antara auditor KAP dengan auditor pemerintahan maupun dengan auditor dari inspektorat terkait dengan kemampuan mereka dalam mendeteksi 
kecurangan laporan keuangan. Melalui perbandingan tersebut akan diperoleh informasi mengenai tingkat generalisasi simpulan yang dapat diambil mengenai faktor-faktor yang mempengaruhi kemampuan auditor dalam mendeteksikecurangan.

\section{REFERENSI}

Abdullatif, M. 2013. Fraud Risk Factors and Audit Programme Modifications: Evidence from Jordan. Australasian Accounting Business and Finance Journal,7 (1): 59-77.

Adnyani, N., Atmadja, A.T., dan Herawati, N.T. 2014. Pengaruh Skeptisisme Profesional Auditor, Independensi, dan Pengalaman Auditor Terhadap Tanggungjawab Auditor dalam Mendeteksi Kecurangan dan Kekeliruan Laporan Keuangan (Studi Kasus pada Kantor Akuntan Publik (KAP) Wilayah Bali). $e$ Journal S1 AK Universitas Pendidikan Ganesha,2 (1): 1-11.

Anggriawan, E.F.2014.Pengaruh Pengalaman Kerja, Skeptisisme Profesional dan Tekanan Waktu Terhadap Kemampuan Auditor dalam Mendeteksi Fraud (Studi Empiris Pada Kantor Akuntan Publik Di DIY).Jurnal Nominal,3 (2): 101-116.

Asare, S.K.,Wright, A., dan Zimbelman, M.F.2015.Challenges Facing Auditors in Detecting Financial Statement Fraud: Insights from Fraud Investigations.Journal of Forensic \& Investigative Accounting, 7 (2): 63-112.

Biksa, I.A.I.dan Wiratmaja, I D.N.2016.Pengaruh Pengalaman, Indepedensi, Skeptisisme Profesional Auditor Pada Pendeteksian Kecurangan. E-Jurnal Akuntansi Universitas Udayana, 17 (3):2384-2415.

Chi, W., dan Huang, H. 2005.Discretionary Accruals, Audit- Firm Tenure and Audit-Partner Tenure: Empirical Evidence from Taiwan. Journal of Contemporary Accounting and Economics, 1 (1): 65-92.

Deis, D.J., dan Giroux, G.A. 1992. Determinants of Audit Quality in the Public Sector. The Accounting Review,67 (3): 462-479.

Festinger, L. 1957. La Teoria De La Disonancia Cognoscitiva. Psicothema,5 (1): 201-206.

Fullerton, R.R.dan Durtschi, C. 2004. The Effect of Professional Skepticsm on the Fraud Detection Skills of Internal Auditors. Working Paper Series. Utah State University School of Accountancy. 
Ghozali,I.2016. Aplikasi Analisis Multivariat dengan Program IBM SPSS 21.Edisi 8.Semarang.Penerbit Universitas Diponegoro.

Glover, S.M., Prawitt, D.F., Schultz, Jr., J.J., dan Zimbelman, M.F.2003.A Test of Changes in Auditors Fraud-Related Planning Judgments since the Issuance of SAS No. 82. Auditing: A Journal of Practice \& Theory,22 (2): 237-251.

Hadi, S. dan Hardiyati, F.I. 2014. Pengaruh Independence In Attitude Dan Pengalaman Terhadap Skeptisisme Profesional Auditor. Jurnal Ekonomi dan Bisnis Islam,8(2): 219 - 234.

Hartadi, B.2012.Pengaruh Fee Audit, Rotasi Kap, Dan Reputasi Auditor Terhadap Kualitas Audit Di Bursa Efek Indonesia.Jurnal Ekonomi dan Keuangan, 16 (1): 84103.

Haryanti, C.S. 2013. Pengaruh Pengalaman Dan Pelatihan Auditor Terhadap Struktur Pengetahuan Tentang Kekeliruan Auditor. Jurnal Ilmiah Dinamika Ekonomi Dan Bisnis,1 (1): 30-41.

Heider, F. 1946. Attitudes and Cognitive Organization. The Journal of Psychology,21: 107-112.

http://www.hukumonline.com/berita/baca/hol14354/kasus-great-river-masuk penyidikan, diakses tanggal 4 April 2017.

Idawati, W. dan Gunawan, A. 2015. Effect of Competence, Independence and Professional Skepticism Against Ability to Detect Fraud Action In Audit Assignment (Survey On Public Accounting Firm Registered In II CPA Territory of Jakarta). Ijaber, 13: 5123-5138.

Jensen, M. C., dan Meckling, W. H. 1976. Theory of The Firm: Managerial Behavior, Agency Costs and Ownership Structure. Journal of Financial Economics,3 (4): 305-360.

Lhaksmi, P.O. 2014.Pengaruh Skeptisisme Profesional, Pelatihan Audit Kecurangan, Dan Independensi Terhadap Kemampuan Auditor Dalam Mendeteksi Kecurangan (Studi di Inspektorat Kabupaten Sleman). Thesis. Universitas Gadjah Mada. Yogyakarta.

Maulana, A. 2014. Kecurangan (Fraud) dalam Akuntansi dan Etika Profesi Akuntansi. http://waterdoor-blanco.blogspot.co.id/2014/11/kecurangan-frauddalam-akuntansi-dan.html, diakses tanggal 10 Agustus 2016. 
Nanda, F.R. 2015.Pengaruh Audit Tenure, Disclosure, Ukuran Kap, Debt Default, Opinion Shopping Dan Kondisi Keuangan Terhadap Penerimaan Opini Audit Going Concern (Pada Perusahaan Yang Terdaftar Pada Index Syariah BEI). Jurnal Ekonomi Manajemen dan Akuntansi I, 24 (1): 41-63.

Noviyanti, S. 2008. Skeptisisme Profesional Auditor dalam Mendeteksi Kecurangan. Jurnal Akuntansi dan Keuangan Indonesia,5 (1): 102-125.

Oktaviani, N. F. 2015. Faktor-Faktor Yang Mempengaruhi Sikap Skeptisisme Profesional Auditor Di Kap Kota Semarang.Skripsi, tidak dipublikasikan, Fakultas Ekonomi Universitas Negeri, Semarang.

Ouyang, B. dan Wan, H. 2013. Does Audit Tenure Impair Auditor Independence? Evidence from Option Backdating Scandals. International Journal of Business and Social Science, 4 (14): 23-33.

Pradana, S.Y., Tarjo, dan Kompyurini, N. 2013. Detection of Fraudulence in Public Sector Organization: Case in Indonesia. The 5th International Conference on Financial Criminology (ICFC).

Pramana, A.C., Irianto, G. dan Nurkholis. 2016. The Influence of Professional Skepticism, Experience and Auditors Independence On the Ability to Detect Fraud. Imperial Journal of Interdisciplinary Research, 2 (11): 1438-1447.

Praptika, P.Y.H. dan Rasmini, N.K. 2016. Pengaruh Audit Tenure, Pergantian Auditor Dan Financial Distress Pada Audit Delay Pada Perusahaan Consumer Goods. E-Jurnal Akuntansi Universitas Udayana, 15 (3): 2052-2081.

Rahayu, S.dan Gudono. 2016. Faktor-Faktor yang Mempengaruhi Kemampuan Auditor dalam Pendeteksian Kecurangan: Sebuah Riset Campuran dengan Pendekatan Sekuensial Eksplanatif. Simposium Nasional Akuntansi XIX, Lampung.

Ramaswamy, V. 2007. New Frontiers: Training Forensic Accountants Within The Accounting Program. Journal of College Teaching \& Learning, 4 (9): 31-38.

Sarwoko, I.2014.Pengaruh Ukuran Kap Dan Masa Perikatan Audit Terhadap Penerapan Prosedur Audit Untuk Mendeteksi Risiko Kecurangan Dalam Laporan Keuangan, Serta Implikasinya Terhadap Kualitas Audit (Survei Pada Kantor Akuntan Publik Anggota Forum Akuntan Pasar Modal). Jurnal Akuntansi,18 (1): $1-20$.

Siregar, S.V., Amarullah, F., Wibowo, A., dan Anggraita, V. 2012. Audit Tenure, Auditor Rotation, and Audit Quality: The Case of Indonesia. Asian Journal of Business and Accounting, 5 (1): 55-74. 
Kompiang Martina Dinata Putri, Dewa Gede Wirama, I Putu Sudana, Pengaruh Fraud......

Sukartha, I M. 2007. Pengaruh Manajemen Laba, Kepemilikan Manajerial, dan Ukuran Perusahaan Pada Kesejahteraan Pemegang Saham Perusahaan Target Akuisisi. Disertasi.Universitas Gadjah Mada.Yogyakarta.

Suryanto, R., Indriyani, S., dan Solayani, H. 2017. Determinan Kemampuan Auditor dalam Mendeteksi Kecurangan. Jurnal Akuntansi dan Investasi, 18 (1): 102-118.

Sutrisno, D.F. 2014. Pengaruh Pengalaman, Keahlian, Situasi Audit, Etika, dan Gender Terhadap Ketepatan Pemberian Opini Auditor Melalui Skeptisisme Profesional Auditor (Studi Kasus Pada KAP Di Bekasi). Jurnal Riset Akuntansi \& Komputerisasi Akuntansi, 5 (2): 1-15.

Tunggal, A.W. 2016. Aspek-Aspek Audit Kecurangan. Edisi 2016. Jakarta: Havarindo.

Yanti, E.F., Yulianti dan Amilin. 2015. Pengaruh Audit Tenure dan Lowballing terhadap Pemberian Opini Audit. Thesis. UIN Syarif Hidayatullah. Jakarta

Yunita, T. 2013. Pengaruh Ketelitian Auditor Dan Kemampuan menilai RisikoRisiko Kecurangan Terhadap Kemampuan Auditor Dalam Pendeteksian Kecurangan Laporan Keuangan. Skripsitidak dipublikasikan, Fakultas Bisnis Universitas Widya Mandala, Surabaya. 